\title{
Legal Protection Towards Copyrighted Music and Song by Websites That Offers Copyrighted Infringing Content Under Indonesian Copyright Law
}

\author{
Sholehaturidlo $^{1 *}$, Syafrinaldi ${ }^{2}$ and Abd Thalib ${ }^{3}$ \\ 1,2,3 PascasarjanaI lmu Hukum, Universitas Islam Riau, 113, Jalan. Kaharuddin Nasution, Pekanbaru, Riau- \\ 28284, Indonesia \\ *Corresponding author email: syafrinaldi@law.uir.ac.id
}

\begin{abstract}
Music and songs are works of art created with full of complexity and ideas. The creating process requires a lot of time, effort, thought and money. Consequently, these music and song has to be be protected in order to reach the goal, that is a sense of justice, legal certainty and the benefits of the law itself. Therefore, our country provides legal protection for music and songs through Law Number 28 of 2014 on Copyright. Piracy carried out by irresponsible individuals by means of downloading songs illegally, has a fatal impact on the creators and copyright holders, such as the loss of profits that should be obtained from the copyrighted song. Piracy of copyrighted music and song is very form of violation to Law Number 28 of 2014.
\end{abstract}

Keywords: Legal Protection, Copyrighted Music, Song

\section{INTRODUCTION}

Indonesia [1] as an archipelagic country, has a very rich diversity of arts and cultures, that corresponds with the diversity of ethnics, ethnic groups and religions which as a whole constitute a national potential that is very necessary to be protected. Therefore, this diversity of arts and cultures is one of the sources of Intellectual Work and Intellectual Property that requires protection by the legislations.

One of the very rapid developments, whether in the past and present as well as in the future is the force of globalization in the socio-economic, technological and cultural fields as well as other fields. Specifically, in the trade sector, globalization has pushed the world into a single common market. On account of that fact, there are demands and needs for adequate regulations and legal framework.

Over and above of that, some countries increasingly rely on their economic and trade activities on products which results are based on human intellectuals, those include creative works in the fields of science, art and literature[2]. This happens seeing as data shows that generally the exports of developing countries in the form of products and natural resources can no longer be proud of[3].

The existence of the internet is perhaps the most visible aspect of globalization and in many ways its driving force. The internet has brought a new reality to mankind. Changing the times and to infinity. A reality that exists many kilometers away from where we are, can be presented right in front of us. Starting from business transactions, chatting, shopping, studying and other activities just like in real physical life [4]

Regardless of its practical and useful nature, on top of that internet brings negative affect, more especially towards irresponsible parties. Those negative impacts include the spread of computer viruses through the internet network, online gambling crimes, pornography that can be freely accessed by all groups, and directly/indirectly impact the Intellectual Property Rights (IPR) as well, specifically copyrighted music and songs that can be easily downloaded via the internet network [5].

Copyright is an exclusive right granted to a creator, arising automatically based on the declarative principle of a creative work which is manifested in a tangible form without reducing restrictions in accordance with the provisions of laws and regulations [6]. Copyright is a right that must be protected due to the fact that the copyright is a work that is created by a person or a society in which a copyright is a form of award assigned for his work. Copyright protection in the era of globalization is very much needed as there is a shift in new habits of society. Copyright protection through Copyright law will certainly provide legal protection for its creators [7]. 
Copyright protection is necessary owing to the fact that Copyright is created with an effort that consumes energy, thought, time and cost which is not easy, cheap and short. This is what gives the copyrighted music and song an economic value that can benefit the songwriter, that right is called the Economic Value of a copyright that has been produced by the author.

Copyrighted music and songs have enormous and real economic potential, both domestically and internationally. Copyrighted music and song works are very popular creations among the public. This corresponds directly to the increase in people's purchasing power of a music and song creation. This increase in purchasing power is what gives music and song creation [8].

Nevertheless, on account of the widespread negative impact of internet use, there are individuals seeking personal gain by providing copyright infringing music and song services that are widespread on sites that are easily accessible to the general public. The increasing activity of copyright piracy occurs as a result of several factors, those inlude public knowledge, economic factors, public attitudes, technological advances, low purchasing power, and a lack of legal action against copyright piracy through certain websites.

The availability to download these copyright infringing content on certain sites are causing people to have second thoughts on purchasing the original content from the legal andofficial platform. Needless to say, purchasing original copyright works to gain access of the content provided by official platforms required certain amount of money. The act of downloading music and songs illegally clearly does not reflect a good and right civil life. Additionally, the said act is a form of betrayal toward government program that aims to provide legal protection toward a copyright, as regulated under the Law Number 28 of 2014 concerning Copyright.

Thus, according to the aforementioned explanation, the author is interested in conducting research with the title "Legal Protection Toward Copyrighted Music and Song by Websites That Offers Copyrighted Infringing Content Under Indonesian Copyright Law".

\section{RESEARCH METHODS}

This research is en empirical research which is drawn directly from concrete empirical evidence by directly observing the field. This legal research has the means for observing the correlation. The data used in conducting this research is the primary data obtained directly, by visiting the respondent for the accuracy of the required data, which is directly related to Legal Protection of Copyright. This research is a descriptive research and aims to determine a certain matter with a high degree of accuracy, narrating the characteristics, conditions and symptoms of an individual or to determine the spread of a symptom, or to determine whether or not there is a relationship between a symptom and other symptoms in society [9].

\section{RESULT AND DISCUSSION}

An intellectual creation and intellectual innovation, specifically under the fields of art, literature and science can result in copyright. According to L.J Taylor in his book Copyright for Librarians, what is protected by copyright is the expression of an idea, not protecting the idea itself. This means that copyright protects what already is in a physical form, not merely an idea [10].

That being so, the laws protected the only the concrete works. In accordance with the mandate of the 1945 Constitution of the Republic of Indonesia, article 1 paragraph (3), which reads "The State of Indonesia is a state based on rule of law". Thus in principle, guided by the Basic Law, the state has several times produced legal products that aims to provide protection toward Copyright, some of these products are:

- Law Number 6 of 1982 on Copyright;

- Law Number 7 of 1987 on Copyright;

- Law Number 12 of 1997 on Copyright;

- Law Number 19 of 2002 on Copyright;

- Law Number 28 of 2014 on Copyright.

Due to the state's commitment in providing legal protection for copyright, the government has made several changes to legal products, in order to create a just, balanced life which aims to create legal certainty for creators of a copyright they have created. As of now, the legal product that still prevails regarding Copyright is Law Number 28 of 2014.

Under copyright, there are are two kinds right attached to it. Those are Moral Right and Economic Right [11]. The law stipulates that moral right and economic rights are:

\section{Moral Rights \\ Article 5}

1) The moral rights as referred to in Article 4 are rights that are eternally inherent to the Author to:

a. Continue to include or to exclude their name on the copy with respect to the public use of their Works;

b. Use an alias or pseudonym;

c. Change their Works to comply with appropriateness in society;

d. Change the title and subtitle of their Works; and

e. Defend their rights in the event of a distortion of Works, mutilation of Works, modification of 
Works, or other acts which will be prejudicial to their honor or reputation.

2) The moral rights as referred to in section (1) cannot be transferred as long as the Author is alive, but the exercise of these rights is transferrable by testament or other reasons in accordance with the provisions of laws and regulations after their death.

3 ) In the event of a transfer of the exercise of moral rights as referred to in section (2), the recipient may release or refuse the exercise of their rights with the condition that the release or refusal to exercise these rights is expressed in writing.

Article 6

In order to protect the moral rights as referred to in Article 5 section (1), the Author may have:

a. Copyright management information; and/or

b. Copyright electronic information.

\section{Economic Rights}

Article 8

Economic rights are the exclusive right of the Author or the Copyright Holder in order to gain economic benefits from the

Works.

\section{Pasal 9}

1) The Author or the Copyright Holder as referred to in Article8 has the economic rights to engage in:

a. Publication of the Works;

b. Reproduction of the Works in all its forms;

c. Translation of the Works;

d. Adaptation, arrangement, or transformation of the Works;

e. Distribution of the Works or their copies;

f. Performance of the Works;

g. Communication of the Works; and

h. Rental of the Works.

2) Every Person who exercises the economic rights as referred to in section (1) is obligated to obtain permission from the Author or the Copyright Holder.

3) Every person is prohibited from exercising Reproduction and/or Commercial Use without any permission from the Author or the Copyright Holder.

The notion of this moral right is to repect the creator and / or the copyright holder of the works and this said moral right is embedded under the copyrighted works. Under the said work lies an existent identity, as a form of respect and appreciation towards the owner and/or the holder of the copyright. Economic rights provide benefits for a work that has an economic value, such as acquiring cash for the benefits of a copyrighted work. It is labeled as economic rights due to the fact that intellectual property rights are property that have value dor money.

Due to its high economic value, certain irresponsible parties decided to commit piracy of music and song works, which will then provide access to the general public that allows them to enjoy those copyrighted work illegally. Without the need to spend a certain amount of money to pay for music or songs you like, this activity will for sure cause economic harm to the creator and / or copyright holder.

Providing legal protection against copyrighted works on the internet might be quite difficult, complex difficulties might be faced considering that there has not been found a truly safe way from piracy or theft as yet [12]. Being as piracy and theft committed in the real world are easier to eradicate for the reason that they exist in the physical world. Contrary to piracy and theft which are done digitally, granted that they ara eradicated, similar sites providing the same service will emerge immediately and soon after.

In order to protect a copyright work, the work must be registered at the Director General of IPR of the Ministry of Law and Human Rights in the area where the creator is domiciled. Legal protection of Intellectual Property Rights is needed because Intellectual Property Rights are the existence of rights that are born because of human intellectual creativity which is manifested in a real work [13].

Therefore, as a result of globalization, ways to obtain and enjoy music and songs has also experienced real shifts and changes. 10 years ago, cassette tape with black pitch was the prima donna of the music industry in its day. Conventional music and song lovers who use a cassette tape always flood the music shop when their favorite artist and / or singer released a new album.

Nevertheless, nowadays, to enjoy these music and songs, one only needs to sit in front of a computer connected to an internet network and Google search the content, there will be options on several websites that offers an option to download or play music which at that time can be enjoyed quickly and easily and for free. There is not only one website that provides copyright infringing music and songs, there are thousands of them, and does not charge anything

The actions of certain irresponsible individuals are of course very detrimental to creators and copyright holders since people, both nationals and international can all enjoy their work without actually having to pay and/or giving royalty to the creator or copyright holder. Even more so, these providers of the copyright infringing contents have 
absolutely no affiliation with the related artist / singer / band / label.

The parties who mastermind the existence of certain websites, which of course contain copyright infringing music and songs which offers free download services have violated article 9 paragraph (1) letter b which states "The Author or the Copyright Holder as referred to in Article 8 has the economic rights to engage in Reproduction of the Works in all its forms".

All the more, according to Farhan as per result of field research, the process of downloading songs on the internet is a retrieval activity, where the song downloader takes and moves the song file to a cellphone or hard disk without losing the original file that is on the downloaded site. From this process, it is apparent that downloading songs is also falls under the multiplication process as it has multiplied the number of songs from one file on the internet site to two, including the results of the download. Moreover, sites that provide such illegal content, do not carry complete information regarding the complete identity of a Copyrighted Work [14].

Farhan additionally said that the act of uploading without the permission of the creator and the copyright holder is an act of violating the economic rights of the creator as stipulated under article 9 paragraph (1) letter g. The violation of economic rights which falls under the announcement of a work. The announcement of the work is the same to uploading a copyrighted work into websites that contain copyright infringing content.

Furthermore, according to the Head of the Criminal Investigation Unit of the Pekanbaru Police [15], in preventing copyright infringement, both music and songs, the police have made preventive and repressive measures. Preventive measure that has been attempted is the establishment of Law No. 28 of 2014 on Copyright, which aims to minimize the possibility of copyright infringement.

This law is deemed necessary as when an idea is transformed into a concrete copyrighted work, the risk of infringement arises. That copyrighted work is very susceptible to intellectual property infringement such as piracy and duplication. Referred to as a violation when an act committed by someone on someone else's Copyright violates the special rights of the Creator and Copyright Holder [16].

It is necessary to grant legal protection toward music and songs, more especially if these music and songs can be illegally obtained through certain websites that offer copyright infringing music and songs. The Indonesian government played a huge part and act as a min role in preventing and eradicating violations in form of piracy, plagiarism, and duplicating of Copyrighted works through preventive efforts. The government, through the Ministry of Communication and Information (Kemenkominfo), can curb and block sites that provides free copyrighted music and songs. Therefore, the internet users can no longer access these websites.

During the process of this blocking practice, blocking is carried out in two ways, those are by means of complaints from the public or creators and copyright holders who are harmed by the copyright infringement, and by finding websites that contain copyright infringing music and songs by the Ministry of Communication and Information itself.

This blocking is such a mandatory action to be carried out by the government, this is in line with the aspiration of our country, whici is to provide protection to creators and copyright holders in the form of music and songs, which are closely related to the inherent economic and moral rights therein. As a result of this legal protection, the creators are no longer reluctant in producing valuable and intangible works of art.

Accordingly, in spite of the action that has been contructed by the Ministry of Communication and Information (Menkominfo) in eradicating these websites that offered copyright infringing content, the law enforcement of the said websites will not be as effective if they are not supported by the system, society and customs in society.

Thus, the objectives of the government in order to provide protection for copyrighted works in the form of music and songs on the internet, cannot be achieved, and creators and copyright holders will still continue to experience losses due to piracy and duplication activities carried out by the irresponsible parties using internet as medium. This of course is very detrimental, both in terms of economic rights and moral rights of creators.

There are several factors that can affect the functioning of law in society [17], those include:

- Rule of law or the regulation itself;

- Officers or law enforcers;

- Facilities or facilities used by law enforcers;

- Community: the environment in which the law applies or is applied;

- Culture: as a result of work, creativity, and taste based on human initiative in social life.

The aforementioned factors are closely related to one another as it is the essence of law enforcement itself. This is also a measure of the effectiveness of law enforcement and law implementation in everyday society.

During law enforcement, there are numerous factors that is causing the effectiveness of the law to decrease, one of which is the lack of awareness of the law in the community. There are still many people who think that the validity of law is only an 
expression, in which humans are not all true and perfect. In fact, this legal awareness is what makes humans obedient and responsible for the law. It would only be a rational human way of thinking where almost everyone will forge their life choices in the most favorable choices for themselves as much as possible.

There are strict sanctions that are to be applied when a Copyright infrinfement occurs, in particular downloading music and songs without permission from the Copyright Owner. According to article 113 paragraph (3) of Law Number 28 of 2014 on Copyright, it is stipulated that "Every person who unlawfully and/or without permission of the Author or Copyright holders infringes the economic rights of the Author as referred to in Article 9 Section (1) point $a$, point $b$, point $\mathrm{e}$, and/or point $\mathrm{g}$ for Commercial Use shall be sentenced to imprisonment for up to 4 (four) years and/or fine up to Rp1,000,000,000.00 (one billion rupiahs)".

Law Number 11 of 2008 on Electronic Information and Transactions (ITE Law) additionally regulates Copyright infringement matter under article 25 which reads "Electronic Information and/or Electronic Records that are created into intellectual works, internet sites, and intellectual works contained therein shall be protected as Intellectual Property Rights under provisions of Laws and Regulations". Violation of these rights is confirmed under article 32 paragraph (1) Jo. Article 48 paragraph (1) of the ITE Law with a maximum imprisonment of 8 (eight) years and / or a maximum fine of Rp. 2,000,000,000 (two billion rupiah) [18].

Some parties have acknowledged the importance of rewarding creators or copyright holders for works of both music and songs and as a result of the globalization of technology, numerous platforms are created in order to facilitate these music and songs legally, solely by downloading applications such as Apple iTunes and Amazon Mp3. Accordingly, provided that someone wishes to listen to music through applications such as Apple iTunes or Amazon Mp3, they have to purchase these works from the official store or platforms and pay certain amount of money set out by the platforms.

Legal protection of Copyright must be provided evidently in order to maintain the interests of the Creator and connoisseurs of the Copyright Work, as well as to provide legal certainty for it. As a result, music and song artists are no longer reluctant to release their best work as the work they produce is protected by law and recognized by the state. Eradicating websites that contain copyright infringing music and songs, must be done with a sustainable scheme so as not to provide loopholes for irresponsible persons in committing copyright violations.

From the perspective of the law, the protection of copyright in Indonesia is considered to be quite satisfying, more especially in eradicating certain websites that contain copyright infringing content. The state is being considerate by accommodating legal certainty toward the creator of the works, beginning with the establishment of Law Number 28 of 2014 on Copyright, the commitment of Ministry of Communication and Information in blocking the sites that provides copyright infringing content is quite pleasing. But in spite all of that, public awareness of the law is still lacking. As a consequence, no matter how many blockings are done, the sites will constantly grow due to the fact that our society refused to pay their respect toward the copyright holder.

\section{CONCLUSION}

The online digital piracy of music and song provided by certain sites still occurred time and again, these sites provided access to copyright infringing content, carried out by irresponsible parties, at the expense of the Creator's Economic Rights and Moral Rights, and at the same time unlawfully granted those Economic Rights for himself. This goes hand in hand with the support of the community itself that allows these event to take place by choosing to enjoy these works illegally rather than purchasing that exact works from the original artists. This is what undermines our legal values and legal morale. This is also associated with the increasingly rapid development of technology, resulting in faster and more efficient method of piracy. These technologicaladvancement provides easier access towards irresponsible parties to commit copyright infringement.

We humans as social beings should have been more thoughtful in respecting someone else's works because these works hold such high artistic, cultural and literary values. One way to respect those works is by purchasing the content from the original artists. That way societies pay their respects and appreciation towards a copyrighted content. Moreover, law enforcer officers especially the Indonesian Police and Mistry of Communication and Information had better form a special work unit that is affiliated to eradicate sites that offered copyright infringing content so that the artists are able to create the high artistic works at ease without worry that their works will be infringe. 


\section{REFERENCES}

[1] Abdul Thalib, Teori dan Filsafat Hukum Modern Dalam Perspektif,. 2005.

[2] Sentosa Sembiring, Prosedur dan Tata Cara Memperoleh Hak Kekayaan Intelektual,. 2001.

[3] Syafrinaldi, Hak Milik Intelektual \& Globalisasi,. 2006.

[4] Wahid, Abdul, Labib, Mohammad, Kejahatan Mayantara (Cyber Crime), PT. Refika Aditama, Bandung, 2010.

[5] Habi Kusno, "Perlindungan Hukum Hak Cipta Terhadap Pencipta Lagu Yang Diunduh Melalui Internet," Fiat Justisia, Lampung, vol. 10, No. 3, 2016.

[6] Law Number, on Copyright,. 2014.

[7] Khoirul Hidayah, Hukum Hak Kekayaan Intelektual Kajian Undang-Undang dan Integrasi Islam, UINMaliki Press, Malang,. 2013.

[8] A. Arya, Titin, "Perlindungan Hukum Terhadap Hak Cipta Lagu dan Musik
Menurut Law Number 28 Tahun 2014," Ganec Swara, Mataram, vol. 13, No. 1, 2019.

[9] Amiruddin, Zainal Asikin, Pengantar Metode Penelitian Hukum, PT Raja Grafindo Persada, Jakarta, 2010.

[10] Arya, Titin, Aline, Op. Cit P. 81AD.

[11] Tommy, T. Keizeirina, "Perlindungan Hukum Hak Cipta Terhadap Karya Cipta Lagu dan Musik Dalam Bentuk Ringtone Pada Telepon Selular," Transpar. J. Huk. Ekon. Medan, vol. 1, No. 1, 2013.

[12] A. Sitompul, Hukum Internet (Pengenalan Mengenai Masalah Hukum di Cyberspace), PT. Citra Aditya Bakti, Bandung, 2004.

[13] Mahmuda Pancawisma Febriharini, "Eksistensi Hak Atas Kekayaan Intelektual Terhadap Hukum Siber," J. Ilm. Fak. Huk. Univ. 17 Agustus 1945, Semarang, vol. 5, No. 1, 2016.

[14] A. Benešová and J. Tupa, “Requirements for Education and Qualification of People in Industry 4.0," vol. 11, n. 2017. 